\title{
Parenteral Use of Iron and Ascorbic Acid (Vitamin C) in Haemodialysis Patients
}

\author{
Mohamed Y. Osman*, Hassan M.Y. Osman ${ }^{*}$, Iman S.Khalii ${ }^{\dagger}$, Iman A. Sharaf ${ }^{\star}$, Redab A. Mahmoud
}

\begin{abstract}
The aim of this work was to study the effect of supplementation of iron and vitamin $C$ therapy to hemodialysis patients, hoping that this therapy is effective in the treatment of anaemia in these patients. In this work, 40 stable hemodialysis patients suffering from severe to moderate anemia not receiving any form of replacement therapy (i.e., neither erythropoietin (EPO) nor iron), were selected and divided into two groups: The first group was treated by injection with ferrosac $100 \mathrm{mg} / 5 \mathrm{ml}$ twice a week for 3 months, and the second group was treated by injection with $500 \mathrm{mg} / 2.5 \mathrm{ml}$ of vitamin $C$ in combination with $100 \mathrm{mg} / 5 \mathrm{ml}$ ferosac twice a week for three months. The results of this study indicated that: There was a significant decrease in both urea and creatinine in hemodialysis patients after i.v. treatment of ferosac alone (100 $\mathrm{mg} / 5 \mathrm{ml})$ "group l" and combined ferosac $(100 \mathrm{mg} / 5 \mathrm{ml})$ with ascorbic acid $(500 \mathrm{mg} / 2.5 \mathrm{ml})$ "group II" twice weekly for 3 months. There was a significant increase in hemoglobin concentration and serum iron in both hemodialysis patient groups (I\&II) after treatment, the highly increase markedly occurred in group II rather than group I after treatment. Moreover, there was a significant decrease in serum ferritin concentration in group I and a more pronounced decrease in group II after treatment, indicating the importance of vitamin C in decreasing the serum ferritin level and therefore the better correction of anemia.
\end{abstract}

Key words: Ascorbic acid; ferrosac; ferritin; hemodialysis.

\section{INTRODUCTION}

The kidney is responsible for maintaining both volume and ionic composition of the body fluids excreting fixed or non-volatile metabolic waste products such as creatinine, urea, uric acid and eliminating exogenous drugs and toxins. It also catabolizes small molecular weight proteins and is responsible for most

metabolic functions ${ }^{(1)}$. The kidney is a major endocrine organ, since it produces renin, erythropoietin, 1,25 dihydroxy cholecalciferol, prostaglandins, and kinins. It also serves as a target organs for many hormones ${ }^{(2)}$. Renal failure is a clinico-biochemical syndrome resulting from failure of the kidney function. Renal failure may be acute but more commonly it is chronic. ${ }^{(3)}$ It is essentially

\footnotetext{
Biochemistry Department Medical Research Institute, Alexandria University

† Department of Internal Medicine Medical Research Institute, Alexandria University
} 
characterized by a sudden decline in renal function, leading to retention of nitrogenous and other waste products, disordered hydrogen ion hemostasis and disturbances of extra-cellular fluid volume and composition(4). Chronic renal failure (CRF) is the result of long-standing, gradually progressing renal disease seen often in people with hypertension; diabetes; and chronic inflammatory diseases. When patients develop end-stage kidney disease, there are a number of treatment modalities available. Hemodialysis is presently the most commonly used treatment for these patients. ${ }^{(5)}$

Anemia may be the first clue to kidney disease. Together with uremia of advanced renal failure, anemia can cause marked fatigue and reduced exercise tolerance. Although the uremia is improFC:IWINDOWS adequate dialysis, it persists with the hematocrit value ranging between $15 \%$ and $30 \%$. Severe anemia is one of the major barriers to rehabilitation in such patients. (6) The goal of therapy for iron deficiency anemia is to supply sufficient iron to correct the anemia and replenish storage iron. The fact that $150 \mathrm{mg}$ of iron are required to synthesize $1 \mathrm{~g}$ of hemoglobin can be used to approximate the amount of parenteral iron necessary for heme synthesis during the correction phase ${ }^{(7)}$.

It is now well established that intravenous (i.v.) iron supplementation is essential in the majority of patients to maintain an optimal iron supply to the bone marrow for red blood cell production. ${ }^{(8,9)}$ Vitamin $C$ may be involved in tyrosin metabolism, microsomal drug metabolism, synthesis of epinephrine and antiinflammatory steroid by the adrenals, folic acid metabolism, and leukocyte functions ${ }^{(10,11)}$. Absorption of $\mathrm{Fe}^{2+}$ is enhanced by simultaneous ingestion of vitamin C. Ascorbic acid, a reducing agent, is able to release iron from ferritin and mobilize iron from the reticuloendothelial system to transferrin. This leads to an increased iron availability. ${ }^{(12)}$ Vitamin $\mathrm{C}$ is an antioxidant. It protects against the harmful effects of pollution, prevents cancer, protects against infection, and enhances immunity ${ }^{(13)}$. 
The aim of this work is to study the effect of combined supplementation of iron and vitamin C therapy to hemodialysis patients, hoping that this therapy is effective in the treatment of anaemia in these patients.

\section{MATERIAL and METHODS}

This study was performed on forty endstage renal disease patients (28 males and 12 females) undergoing maintenance hemodialysis. Mean age was 50 years (range 22-70 years). All the patients studied had been on hemodialysis for at least one year before being included in the study.

All patients were dialyzed in Nephrology Unit, Medical Research Institute (Alexandria University, Egypt). All patients were anemic, blood hemoglobin averaged $7.64 \mathrm{~g} / \mathrm{dl}$ and serum ferritin was less than $300 \mathrm{ng} / \mathrm{dl}$. They were divided randomly into two groups:

Group I: $\quad$ Comprising 20 hemodialysis patients were intravenously infused ferrosac, i.e., ferric-hydroxide saccharate complex, manufactured by SPIMACO, Saudia Arabia,
$100 \mathrm{mg} / 5 \mathrm{ml}$ ferrosac twice a week for three months.

Group II: $\quad$ Comprising 20 hemodialysis patients were supplemented intravenous, 100 $\mathrm{mg}$ ferrosac combined with $500 \mathrm{mg} / 2.5 \mathrm{ml}$ vitamin $\mathrm{C}$ twice a week for three months.

Preparation of the samples: Blood samples were collected before dialysis session by routine venupuncture using silicon red evacuated blood tubes without anticoagulant and EDTA tubes. Separation of serum was obtained by centrifugation at $500 \mathrm{~g}$ for $10 \mathrm{~min}$. Serum was divided into aliquots and frozen and stored at $-20 \mathrm{oC}$ until analyzed.

The prepared samples were used to determine the following parameters:

1- Serum urea using the method of Orsonneau et al.,(14) 2- Serum creatinne. using the method of Rosano et al., (15) 3Serum albumin using the method of Doumas, ${ }^{(16)}$ 4- Blood haemoglobin using the method of Dacie and Lewis.,(17) 5- Serum iron using the method of Burtis 
and Ashwood(18), and 6- Serum ferretin using the method of Zanella et al. (19)

Measurements were carried out on Labo Med, Inc. USA spectrophotometer.

\section{Results}

Table 1 shows the mean values $\pm \mathrm{S}$.E of blood urea, creatinine, albumin, haemoglobin, iron, and ferritin levels in patients group receiving intravenous ferrosac for 3 months (group I).

It has been found that there was a significant decrease in urea and creatinine levels after treatment, while there was no significant difference in albumin concentrations before and after treatment. A significant increase was found in haemoglobin and iron concentrations together with a significant decrease in ferritin levels in heamodialysis patients after treatment than before treatment with ferrosac. Table 2 shows the mean values \pm S.E of the same parameters mentioned above in patients group receiving intravenous ferrosac and ascorbic acid (group II).

It has been found that there was a significant decrease in levels of urea and creatinine after treatment. Also there was a significant increase in albumin, haemoglobin, and iron concentrations together with a significant decrease in ferritin levels after treatment than before treatment in haemodialysis patients receiving combined ferrosac and ascorbic acid.

\section{DISCUSSION}

Renal failure disease has been documented to be associated with excessive production of free radicals, which leads to a state of oxidative stress. This condition may be raised due to the decrease of serum level of antioxidants like vitamins $\mathrm{C}$ and $\mathrm{E}$. At the same time, significant and debilitating anemia occurs in patients with end-stage renal disease(20). Anemia of chronic disease (ACD) is often occurring in subjects suffering from chronic inflammatory disorders. 
The underlying diversion of iron traffic leads to a withdrawal of the metal from the sites of erythropoiesis and the circulation to the storage compartment in the reticuloendothelial system, thus resulting (at the same time) in hypoferremia and hyperferritinemia. (20) 
Table (1): The statistical analysis of the studied parameters in hemodialysis patients before and after intravenous treatment with iron therapy (group I).

\begin{tabular}{|c|c|c|c|c|c|}
\hline parameters & & $\begin{array}{l}\text { No. of } \\
\text { cases }\end{array}$ & Mean & SE & $\mathbf{P}$ \\
\hline \multirow{2}{*}{$\begin{array}{c}\text { Urea } \\
\text { (mg/dl) }\end{array}$} & B & \multirow[t]{2}{*}{20} & 190.35 & 10.58 & \\
\hline & A & & 165.94 & 9.55 & $0.01^{*}$ \\
\hline \multirow{2}{*}{$\begin{array}{c}\text { Creatinine } \\
\text { (mg/dl) }\end{array}$} & B & \multirow[t]{2}{*}{20} & 12.14 & 0.61 & \\
\hline & A & & 11.31 & 0.57 & $0.004^{\star \star *}$ \\
\hline \multirow{2}{*}{$\begin{array}{l}\text { Albumin } \\
\text { (gm/dl) }\end{array}$} & B & \multirow[t]{2}{*}{20} & 3.50 & 0.07 & \\
\hline & A & & 3.63 & 0.09 & NS \\
\hline \multirow[t]{2}{*}{ Hemoglobin } & B & \multirow[t]{2}{*}{20} & 8.28 & 0.37 & \\
\hline & A & & 9.61 & 0.41 & $0.000^{* * *}$ \\
\hline \multirow[b]{2}{*}{ (ug/dl) } & B & \multirow[t]{2}{*}{20} & 69.18 & 5.52 & \\
\hline & A & & 94.18 & 6.57 & $0.047^{*}$ \\
\hline \multirow[t]{2}{*}{ Ferritin } & B & \multirow[t]{2}{*}{20} & 31.61 & 1.6 & \\
\hline & A & & 17.81 & 1.01 & $0.000^{\star * *}$ \\
\hline
\end{tabular}

P: probability of error

*: statistically significant difference at $<0.05$

***: statistically significant difference at $<0.001$

NS: not significant
B: before treatment

A: after treatment 
Table (2): The statistical analysis of the studied parameters in hemodialysis patients before and after intravenous treatment with combined iron and ascorbic acid therapy (group II).

\begin{tabular}{|c|c|c|c|c|c|}
\hline parameters & & $\begin{array}{l}\text { No. of } \\
\text { cases }\end{array}$ & Mean & SE & $\mathbf{P}$ \\
\hline \multirow[t]{2}{*}{ Urea } & B & \multirow[t]{2}{*}{20} & 191.47 & 9.29 & \\
\hline & A & & 173.40 & 10.26 & $0.042^{*}$ \\
\hline \multirow{2}{*}{$\begin{array}{c}\text { Creatinine } \\
(\mathrm{mg} / \mathrm{dl})\end{array}$} & B & \multirow[t]{2}{*}{20} & 11.85 & 0.53 & \\
\hline & A & & 10.65 & 0.48 & $0.000^{* * *}$ \\
\hline \multirow{2}{*}{$\begin{array}{l}\text { Albumin } \\
\text { (gm/dl) }\end{array}$} & B & \multirow[t]{2}{*}{20} & 3.45 & 0.086 & \\
\hline & A & & 3.70 & 0.082 & $0.000^{* * *}$ \\
\hline \multirow[t]{2}{*}{ Hemoglobin } & B & \multirow[t]{2}{*}{20} & 7.61 & 0.22 & \\
\hline & A & & 11.97 & 0.26 & $0.000^{* \star *}$ \\
\hline \multirow[b]{2}{*}{$(\mu \mathrm{g} / \mathrm{dl})$} & B & \multirow[t]{2}{*}{20} & 60.17 & 5.36 & \\
\hline & A & & 118.93 & 9.68 & $0.047^{*}$ \\
\hline \multirow[t]{2}{*}{ Ferritin } & B & \multirow[t]{2}{*}{20} & 24.80 & 1.69 & \\
\hline & A & & 10.15 & 1.12 & $0.000^{* * *}$ \\
\hline
\end{tabular}

P: probability of error

*: statistically significant difference at $<0.05$

***: statistically significant difference at $<0.001$
B: before treatment

A: after treatment 
The present study was done to evaluate the effect of administration of iron alone (ferrosac, $100 \mathrm{mg} / 5 \mathrm{ml}$ twice a week for 3 months), as well as, combined iron and ascorbic acid $(100 \mathrm{mg} / 5 \mathrm{ml}$ ferrosac +500 $\mathrm{mg} / 2.5 \mathrm{ml}$ vitamin $\mathrm{C}$ twice a week for 3 months) on serum urea, creatinine, albumin, blood hemoglobin, serum iron and ferritin. The study reveals significant differences in serum urea and creatinine levels in hemodialysis patients after i.v. treated with ferrosac alone and more pronounced significance if combined with ascorbic acid. Intravenous ascorbic acid can effectively improve the functional iron deficient erythropoiesis associated with iron overload in hemodialysis patients ${ }^{(11)}$.

This study indicated a significant increase in hemoglobin concentration and serum iron in hemodialysis patients after i.v. treatment with ferrosac

(100 mg/5ml) twice weekly for 3 months. While, a highly significant increase in hemoglobin concentration and in serum iron in hemodialysis patients after treatment with combined ferosac $(100 \mathrm{mg} / 5 \mathrm{ml})$ and ascorbic acid $(500 \mathrm{mg} / 2.5 \mathrm{ml})$ twice weekly for 3 months occurred. The increase markedly occurred after the combined administration and it was highly significant. Since vitamin $\mathrm{C}$ is one of the most important antioxidants existing in plasma, it increases intestinal iron absorption and induces iron mobilization from inert tissue stores, including reticuloendothelial system, and may improve iron availability. It has also a role in the enzymatic incorporation of iron into protoporphyrin for heme synthesis.(21)

This was in accordance with the results of Giancaspro et al.,(22) who obtained only a partial correction of anemia and functional iron deficiency together with a reduction of serum ferritin levels within the treatment with i.v. vitamin C (500 mg) 3 times per week for 3 months, which indicated the importance of vitamin $\mathrm{C}$ in decreasing the serum ferritin level. Tarng et al.(23) found that some patients had a dramatic response to intravenous ascorbic acid (300 mg, 3 times/week) with a 
significant decrease in serum ferritin and significant increase in their hemoglobin, reticulocyte index, and serum iron concentration.

From this study, we recommend the administration of iron combined with ascorbic acid in hemodialysis patients suffering from anemia to increase iron absorption and improve hemoglobin concentration.

\section{REFFERENCES}

1- Wright FS. Sites and mechanisms of potassium transport along the renal tubules. Am J Physiol. 1982; 243: 526-30.

2- Hricik DE, Chung-Park M, Sedor JR. Glomerulonephritis. N Engl J Med. 1998; 339:888-99.

3- Lancaster LE, Pitman NJ. Systemic manifestations of renal failure. American Nephrology Nurses. 2001; 117-58.

4- Parker KP. Acute and chronic renal failure. In: Parker Pitman NJ. Contemporary Nephrology Nursing. American Nephrology Nurses, Association. 1998; 199-265.

5- Colton CK, Lowrie EG. Hemodialysis: Physical principles and technical considerations. In: Brener BM and Rector FC. The Kidney. Philadelphia: W.B. Saunders Co.; 2nd ed. 1981.

6- McGonigle RSR, Wallin JD, Shadduck RK, Fisher JW. Erythropoietin deficiency and inhibition of erythropoiesis in renal insufficiency. Kidney Int 1984; 24: 437-44.
7- Eschbach JW, Cook JD, Scribner BH, Finch CA. Iron balance in hemodialysis patients. Ann Intern Med. 1977; 87: 710-3.

8- $\quad$ Alvo M, Elgueta L, Aragon H, Cotera A. Correction of anemia in hemodialysis, effect of intravenous iron without erythropoietin. Rev Med Chil. 2002; 130(8): 865-8.

9- Watson A. Iron management during treatment with recombinant human erythropoietin in chronic renal failure. J Clin Pharmacol. 1993; 33:1123-38.

10- Kojo S. Vitamin C: Basic metabolism and its function as an index of oxidative stress. Curr Med Chem. 2004; 11(8): 1041-64.

11- Sies H, Staw W. Vitamin E and C, BetaCarotene, and other carotenoide as antioxidants. Am J Clin Nutr. 1995; 62(6): 1315-21.

12- Bridges KR, Hoffman KE. The effects of ascorbic acid on the intracellular metabolism of iron and ferritin. $\mathrm{J}$ Biol Chem. 1986; 251:14273-7.

13- Hanck AB. Vitamin $C$ and cancer. Prog Clin Biol Res. 1988; 259: 307-20.

14- Orsonneau J, Massoubre C, Cabanes M, Lustenberger $P$. Simple and sensitive determination of urea in serum and urine. Clin Chem. 1992; 38:619-23

15- Rosano T, Ambrose RT, Wu AHB. Candidate reference method for determining creatinine in serum: method development and interlatoratory validation. Clin Chem. 1990; 36:1951-5

16- Doumas BT, Watson WA, Biggs HG. Albumin standards and the measurement of serum albumin with bromcresol green. Clin Chem Acta. 1971; 31(1):87-96.

17- Dacie J, Lewis S. Practical hematology. 8th ed. London: J\&A Churchill LTD; 1991. pp216-217. 
18- Burtis CA, Ashwood ER. Tietz fundamentals of clinical chemistry. 4th ed. Philadelphia: WB Saunders; 1996.

19- Zanella A, Gridelli L, Berzuini A, Colotti MT, Mozzi F, Milani $S$, et al. Sensitivity and predictive value of serum ferritin and free erythrocyte protoporphyrin for iron deficiency. J Lab Clin Med. 1989; 133:738.

20- Alvarez-Hernadwz X, Licega J, Mckay I, Brock JH. Induction of hypoferremia and modulation of macrophage iron metabolism by tumor necrosis factor. Lab Invest. 1989; 61:319-22.
21- Goldberge A. The enzymic formation of haem by the incorporation of iron into protoporphyrin; Importance of ascorbic acid, ergothioneine and glutathione. Birt $\mathrm{J}$ Haemat. 1959;5:150-7.

22- Giancaspro V, Nuzziello M, Pallotta G, Sacchetti A, Petrarulo F: Intravenous ascorbic acid in hemodialysis patients with functional iron deficiency: A clinical trial. J Nephrol. 2000; 13:444-9.

23- $\quad$ Tarng DC, Wei YH, Huang TP, Kuo, Yang WC. Intravenous ascorbic acid as an adjuvant therapy for recombinant erythropoietin hemodialysis patients with hyperferritinemia. Kidney International. 1999; 55:2477-85. 